\title{
URGENSI BEKERJA DALAM ALQURAN
}

\author{
Rahmad Kurniawan \\ Institut Agama Islam Negeri Palangka Raya \\ rahmad.kurniawan@iain-palangkaraya.ac.id
}

Received : 2019-04-06 ; Accepted : 2019-04-18 ; Published : 2019-04-24

\begin{abstract}
This article examines the urgency of working based on the Qur'an, it is focused on Surah At-Taubah verse 105 and Surah Al-Jumuah verses 9-11. The method that used in this article is library method; meanwhile normative approach is the approach that used to interpret the Qur'an, specifically. Content analysis and hermeneutics is used to analyzed. The results indicate that the urgency of working in the Qur'an contained in Surah At-Taubah verse 105 concerning the importance of hardworking which will match good results and also emphasizing that the significance of the assessment of work from Allah, the judgment of Rasulullah, and the judgment of believers towards someone's (work) achievements. Furthermore, in Surah Al-Jumuah verses 9-1 declared that if all obligations to Allah have been fulfilled, then someone can back to economic activity or work. Regarding the command to work and worship, when a human works, do not forget worship because not only the world is preferred, but afterlife is prioritized too.
\end{abstract}

Keywords: urgency, work, Qur'an

Bekerja adalah fitrah manusia untuk mencari rezeki sebagai penopang kehidupan pemenuhan kebutuhan. Pemenuhan kebutuhan baik sandang, pangan dan papan untuk manusia bias bertahan hidup dalam memuhi kebutuhannya. Bekerja ialah segala aktifitas yang dilakukan dinamis dan tujuannya untuk pemenuhan kebutuhan tertentu baik jasmani maupun rohani, dan di dalam mencapai tujuannya.

Bekerja adalah suatu hal kewajiban dan juga merupakan perintah dari Allah SWT, hal ini berlaku semenjak manusia pertama diturunkan di muka Bumi yakni Nabi Adam AS, hal ini juga hingga Nabi Muhammad SAW. Bekerja menurut persfektif Islam merupakan hal terpenting dalam kegiatan ibadah dan juga jihad, jika halnya seseorang konsisten terhadap hukum yang ditetapkan Allah SWT, suci dalam hal niatnya, serta juga dilakukan untuk pemenuhan kebutuhan baik dari diri sendiri, pemeuhan kebutuhan keluarga, bermasyakarakat maupun bernegara.

DOI : 10.23971/tf.v3i1.1240

Transformatif (Journal Islamic Studies) 3 (1), Hal 42-67

Copyright (c) 2019 by Transformatif, p-ISSN 2580-7056; e-ISSN 2580-7064 
Islam dalam hal memandang dan melihat bekerja sangat menjunjung tinggi nilai suatu pekerjaan, bahkan ada dalam suatu hadis Rasullulah SAW:

“... jikalau ada seseorang keluar dari rumahnya untuk melaksanakan perkerjaan untuk membiayai anaknya yang masih kecil, maka ia telah berusaha Fisabililah. Jikalau dia keluar bekerja untuk kedua orang tuanya yang sudah kanjut usia, maka dia fisabilillah. Jikalau dia bekerja untuk dirinya sendiri agar tidak sampai meminta-minta pada orang lain, hal itupun juga fisabilillah. Jikalau ia bekerja untuk keluarganya, maka dia fisabilillah. Tetapi apabila dia bekerja untuk pamer atau untuk bermegah-megahan, maka itulah Fisabili Syaithan atau karena mengikuti jalan setan." (HR.Thabrani,2/148).

Hadis tersebut mengisyaratkan menyamakan kerja yang bersungguhsungguh (etos kerja) dengan $f i$ sabillilah. Nabi Muhammad SAW sendiri bekerja menjadi seorang pedagang, kepala Negara dan agama, beliau merupakan sosok panutan bagi umat manusia. Beliau bukan hanya menguasai ilmu agama tetapi juga ilmu muamalah.

Di dalam Alquran sebagai acuan pertama dalam sumber hukum Islam sangatlah dianjurkan untuk bekerja. Banyak ayat-ayat alquran yang menjelaskan pentingya bekerja dalam Alquran, sehingga posisi bekerja dalam Islampun sangatlah penting untuk dilaksanakan. Dari hal tersebut penting kiranya untuk mengetahui dalil urgensi perintah bekerja.

\section{Metode}

Metode yang digunakan dengan metode studi kepustakaan (library research). Penelitian tentang urgensi bekerja dalam Alquran merupakan penelitian normatif tafsir ekonomi yang dianalisis dengan pendekatan normatif tafsir, tektsua. Analisis data yang digunakan yaitu dengan menggunakan content analysis dan hermeneutic. 


\section{Deskripsi teoritik}

\section{Definisi Kerja}

Pengertian kerja dalam kamus besar bahasa Indonesia yaitu kegiatan melakukan sesuatu; sesuatu yang dilakukan (diperbuat); sesuatuyang dilakukan untuk mencari nafkah; mata pencaharian. (Tim Penyusun, 2008) Selanjutnya pengertian bekerja yaitu melakukan suatu pekerjaan (perbuatan): berbuat sesuatu. (Tim Penyusun, 2008)

Pengertian kerja menurut Toto Tasmara adalah segala aktivitas yang dilakukan baik secara dinamis dan juga mempunyai tujuan untuk pemehunan kebutuhan tertentu baik secara jasmani maupun rohani, untuk mencapai tujuan tersebut akan berusaha dengan sangat maksimal dan penuh kesungguhan untuk mewjudkan prestasi sebagai pembuktian dirinya dalam mengabdi kepada Allah SWT. (Toto Tasmara, 2002)

Menurut Toto Tasmara, tidak semua hal aktifitas yang dilakukan oleh manusia dapat digolongkan dengan kerja, karena dalam kerja ada aspek yang memang harus terpenuhi secara logika, yaitu:

a. Akitifitas yang dilakukan karena ada suatu dorongan untuk memunculkan sesuatu hal sehingga muncullah rasa tanggung jawab yang besar untuk mebuahkan karya atau produk yang berkualitas tinggi.

b. Sesuatu yang sudah direncanakan tersebut dikerjakan karena kesengajaan atau sesuatu hal yang sudah direncanakan. (Toto Tasmara, 2002)

Kerja atau dalam Bahasa arabnya amal dalam Islam dapat didefinisikan dengan sesuatu hal yang bermakna yang umum atapun dengan makna yang khusus. Arti amal dengan makna umum adalah dengan melakukan atau meninggalkan sesuatu hal perbuatan yang diperintahkan atau sesutau hal yang dilarang dalam agama Islam yang meliputi perbuatan yang mengarahkan kepada kebaikan atau kejahaatan. Perbuatan yang baik dinamakan amal sholeh dan perbuatan jahat dinamakan perbuatan maksiat. 
Selanjutnya pengertian kerja atau amal dengan makna secara khusus adalah melaksanakan pekerjaan atau usaha yang merupakan bagian dari unsur terpenting dan starting point bagi proses kegiatan ekonomi secara keseluruhannya. Kerja atau amal dalam makna secara khusus menurut Islam terbagi menjadi:

a. Kerja yang bercorak jasmani (fisik)

b. Kerja yang bercorak aqli atau pikiran (mental)

Berikutnya menurut hadits rasulullulah tentang bekerja yakni:

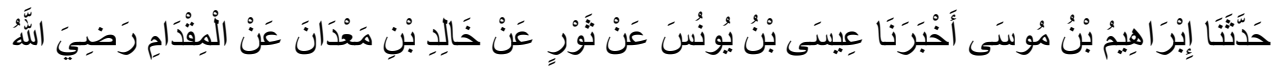

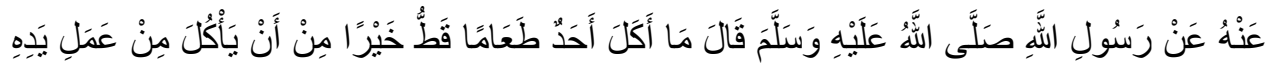

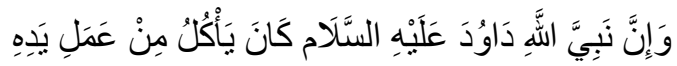

(BUKHARI - 1930) : Telah menceritakan kepada kami Ibrahim bin Musa telah mengabarkan kepada kami 'Isa bin Yunus dari Tsaur dari Khalid bin Ma'dan dari Al Miqdam ra dari Rasulullah SAW bersabda: "Tidak ada seorang yang memakan satu makananpun yang lebih baik dari makanan hasil usaha tangannya sendiri. Dan sesungguhnya Nabiyullah Daud AS memakan makanan dari hasil usahanya sendiri".(Kutub al-Tis'ah, t.t.)

Dari keterangan hadis tersebut Rasulullah SAW terdapat kesimpulan bahawa konsep kerja menurut Islam adalah meliputi segala bidang ekonomi yang dibolehkan oleh syariat sebagai balasan kepada upah atau bayaran, pekerjaan itu ada yang bercorak jasmani (fisik) seperti kerja buruh, pertanian, pertukangan tangan dan sebagainya atau kerja bercorak aqli (mental) seperti jawatan pegawai, baik yang berupa perguruan, iktisas atau jawatan perkeranian dan teknikal dengan kerajaan atau swasta.

Para sahabat lebih identik menggunakan perkataan pekerja atau amil untuk jabatan orang yang ditugaskan menjadi petugas pemerintahan umpamanva jabatan kadi, gubernur dan jabatan lainnya. Lebih lanjut segala bentuk kerja dan usaha yang diperbolehkan oleh syariat baik yang bersifat kebendaan atau abstrak atau gabungan dan kedua-duanya adalah dianggap oleh agama Islam sebaga "kerja". Segala bentuk kerja yang 
bermanfaat dalam Islam dan yang sekecil-kecilnya seperti tukang sapu hingga kepada yang sebesar-besarnya seperti menjadi menteri atau kepala negara adalah merupakan kerja atau amal sekalipun berlainan peringkat dan kelayakan yang diperlukan untuknya.

Berdasarkan hal tersebut maka menurut pandangan Islam, perkerjaan yang dilakukan oleh individu, masyarakat ataupun seluruhnya dan semua peringkat adalah suatu pekerjaan.

\section{Tujuan Bekerja dalam Islam}

Secara umum tujuan bekerja adalah untuk mencari nafkah atau mata pencahairan dalam memenuhi keutuhannya untuk bertahan atau melangsungkan kehidupannya. Dalam Islam bekerja bisa sebagai penopang kehidupan dan juga sebaga sarana dalam beribadah kepada Allah SWT. Lebih lanjut tujuan bekerja dalam Islam yaitu:

a. Bekerja untuk Keridaan Tuhan

Tujuan bekerja dalam Islam tidaklah hanya untuk memenuhi naluri yakni hidup untuk kepentingan perut. Islam memberikan arahan yang jelas kepada suatu tujuan filosofi yang luhur. Mempunyai tujuan yang mulia dan juga ideal yang sempurna yakni berta'abbud, memperhambakan diri, mencari keridaan Allah SWT. Semua usaha dan aktvitas seoarang mu'min, baik yang bercorak duniawiah maupun yang bercorak ukhrawiyah pada hakekatnya tertuju pada suatu titik tumpuan falsafah hidup muslim, yakni keridaan Allah SWT.

b. Bekerja untuk Memenuhi Kebutuhan Hidup

Kita hidup di dunia ini mempunyai sejumlah kebutuhan yang bermacam-macam yang dibagi ke dalam tiga tingkatan:

1) Kebutuhan pokok atau dharuriyat

2) Kebutuhan sekunder atau tahsiniyat

3) Kebutuhan tersier atau mewah atau hajiyat

Kebutuhan-kebutuhan manusia sesuai dengan urutannya, maka sudah barang tentu kebutuhan primer itulah yang mendesak yang tidak boleh diabaikan. Kebutuhan kedua dan ketiga masih bisa ditangguhkan, 
tetapi kebutuhan primer wajib dipenuhi secepat mungkin, sebab jika tidak terpenuhi, maka sunnatullah akan menjadikan manusia merana dan menderita bahkan menggoncangkan sendi-sendi lahir dan bathinnya.

c. Bekerja untuk Memenuhi Nafkah Keluarga

Islam memerintahkan makan yang halal dan memakai pakaian yang sopan menutup aurat yang kesemuanya itu dapt diwujudkan dengan melalui kerja, dan tanggung jawab kepada laki-laki, suami atau kepala rumah tangga dalam memenuhi hajat keluarga. Pihak suami atau kepala rumah tangga adalah bertanggung jawab atas keberesan dan keharmonisan ruma tangganya.

Kewajiban maupun tanggung jawab tersebut menimbulkan konsekuensi- konsekuensi bagi pihak suami sebagai kepala keluarga. Fungsi dan tanggung jawabnya itulah yang mengharuskan dia bertanggung jawab terus bergerak dan rajin bekerja.

d. Bekerja untuk Kepentingan Amal Sosial (Sedekah)

Diantara tujuan bekerja adalah bahwa dengan hasil kerjanya itu dapat dipakai melakukan salah satu perintah agama, amal sosial (sedekah). Ajaran Islam yang luhur dan indah senantiasa menggalakkan manusai agar terus berbuat ihsan dimanapun dan kapanpun dengan berbuat amal social kepada sesama manusia.

e. Bekerja untuk Kepentingan Ibadah

Di samping hubungan yang jelas antara industri dengan amal social (ihsaniah), maka dalam bidang ibadah juga mempunyai hubungan yang jelas, karena kegiatan perindustrian menunjang kelancaran ibadah kepada Allah SWT.

f. Bekerja untuk Menolak Kemungkaran

Tujuan lain yang ideal dari bekerja atau berusaha adalah dalam hal menolak sejumlah kemungkaran yang mungkin dapat terjadi pada diri orang yang tidak bekerja atau menganggur. Seseorang yang mempunyai pekerjaan atau usaha berarti salah satunya menghilangkan sifat dan sikap yang buruk berupa sifat malas dan juga pengangguran. Sebab adanya 
kesempatan kerja yang terbuka menutupi keadaan-keadaan mengarah kepadas perbuatan yang negatif. (Hamzah Ya'qub, 2001)

\section{Pembahasan}

\section{Dalil Urgensitas Bekerja dalam Alquran}

Dalil urgensitas bekerja banyak ditemukan dalam Alquran, salah satunya yang penulis ambil yaitu Q.S At-Taubah ayat 105 mengenai pentingnya perintah bekerja keras yang akan menuaikan hasil yang baik. Selanjutnya surat yang diambil yaitu Q.S. Al-Jumuah ayat 9-11 mengenai perintah bekerja dan beribadah, ketika bekerja jangan melupakan ibadah karena tidak hanya dunia yang diutamakan, akherat juga harus diutamakan. Berikut penjelasan terkait dengan urgensi bekerja dalam Alquran mengenai surat yang penulis cantumkan:

\section{a. Surah al-Taubah:105}

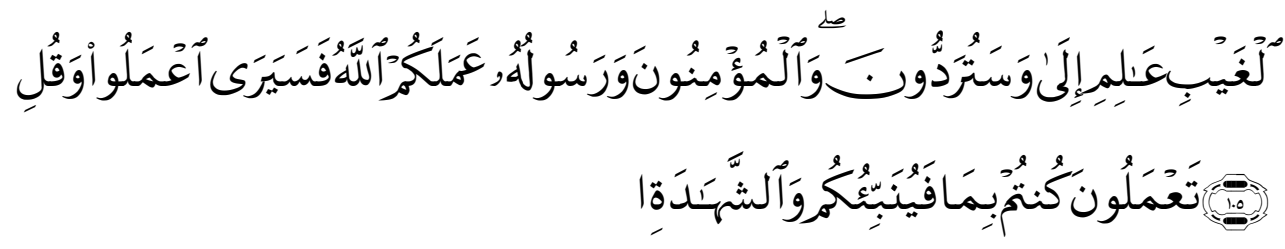

Artinya: " dan Katakanlah: "Bekerjalah kamu, Maka Allah dan Rasul-Nya serta orang-orang mukmin akan melihat pekerjaanmu itu, dan kamu akan dikembalikan kepada (Allah) yang mengetahui akan yang ghaib dan yang nyata, lalu diberitakan-Nya kepada kamu apa yang telah kamu kerjakan." (Q.S At-Taubah [09:105]).

1) Makna Mufradat
a) bekerja
b) أَخَيْبَyaitu alam gaib, yang tidak tampak atau tidak nyata.

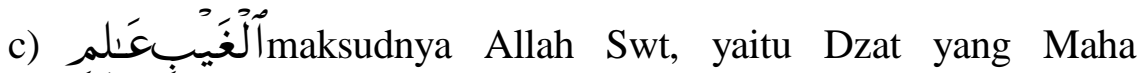 Mengetahuialam gaib.

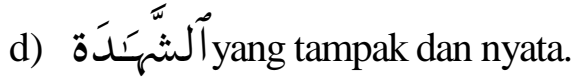


2) Asbabun Nuzul Ayat

Asbabun Nuzul dalam Q.S At-Taubah ayat 105, tidak secara ekplisit dijelaskan mengenai $a s b a b$ turunnya ayat. Menurut kitab Lubabun Nuqul fii Asbabin Nuzul hanya menjelaskan bahwa sebab turunnya ayat sebelumnya, yaitu ayat ke-102. Menurut kitab tersebut menerangkan tentang peristiwa Abu Lubabah dan lima orang lainnya tidak ikut berperang. Peristiwa tersebut diriwayatkan oleh Ibnu Abbas bahwa Rasullah pergi berperang. (Jalaluddin AsSuyuthi, 2009)

Menurut riwayat tersebut menceritakan mereka merenung dan menyesal, dan berkata "kita akan celaka. Disaat rasullululah SAW dan para sahabat sedang berperangg, mereka malah tinggal bersama anak-anakdan para wanita dalam keadaajn tenang dan nyaman, mereka pun bersumpah untuk mengikatkan diri di tiang.".

Selesai mereka bersumpah, kemudian merekapun melaksanakan apa yang telah mereka katakan, tetapi tidak keseluruhan dari mereka melakukannya, ada tiga orang yang tidak melakukan sumpahnya. Sepulang dari peperangan, Rasulullah SAW lalu bertanya, "siapakah orang-orang yang terikat ditiang ini?" ada seseorang yang menjawab, "ini Abu Lubabah dan tamantemannya yang tidak ikut berjihad. Mereka melaksanakan sumpah tidak akan melepaskan ikatan tersebut kecuali jika Rasulullah sendiri yang melepaskan mereka". Kemudian Rasulullah berkata, "aku tidak akan melepaskan mereka kecuali jika aku diperintahkan oleh Allah SWT". Karena adanya peristiwa itu, lalu Allah menurunkan Q.S At Taubah ayat 102, dan kemudian Rasulullah melepaskan mereka dan memaafkan mereka.

3) Tafsir Ayat

Dan katakanlah Muhammad kepada mereka (orang yang berpura-pura beriman padahal sesungguhnya tidak beriman), i'malu (bekerjalah kalian), niscaya Allah Swt dan Rasul-Nya, pasti akan 
melihat (menyaksikan) prestasikalian, bahkan Allah akan memberikan pembalasan atas amal perbuatanmu itu dalam bentuk kekayaan, kemampuan, kemuliaan, keleluasaan, dankeutamaan rezeki yang tiada tara. (Muhammad Amin Suma, 2015)

Demikian pula, Rasulullah dan Orang-orang beriman lainnya, akan menyaksikan prestasi kerja kalian semua sehingga mereka akan memberikan hak-hak kalian di dunia ini, adapun di akhirat kelak, itu hendak dikembalikan (diserahkan) kepada Zat yang Maha Mengetahui hal-hal yang gaib, yang Maha Mengetahui hal-hal yang bersifat rahasia dan samar sekalipun; serta Dzat yang juga Maha Mengetahui hal-hal yang tampak dan hadir (ada), dan Allah dipastikan akan memberikan balasan terhadap amal perbuatan kalian semua, baik yang berhubungan dengan prestasi kerja duniawi (bermotifkan ekonomi) maupun yang berhubungan dengan nilai-nilai ukhrawi. Singkatnya, jika kerjanya baik, maka itu akan metldapatkan imbalan yang baik, dan sebaliknya, manakala perbuatannya buruk, maka akan mendapatkan imbalan yang buruk pula. (Muhammad Amin Suma, 2015)

Ayat ini menurut M. Quraish Shihab bertujuan untuk mendorong umat manusia agar lebih menginstropeksi diri dan mengawasi amal-amal atau pekerjaan mereka, dengan cara mengingatkan mereka bahwa setiap amal atau perbuatan yang baik dan buruk memiliki hakekat yang tidak dapat disembunyikan, dan mempunyai saksi-saksi yang mengetahui dan melihat hakekatnya, yaitu Allah Swt, Nabi Muhamaad SAW, dan saksi-saksi dari umat Islam. Setelanya Allah akan membuka tabir penutup yang menutupi mata mereka yang mengerjakan amal-amal atau perbuatan tersebut pada hari kiamat, sehingga mereka pun mengetahui dan melihat hakekat amal mereka sendiri. (M. Quraish Shihab, 2002) 
Dari uraian tafsir tersebut, dapat dikatakan bahwa umat manusia diperintahkan oleh Allah untuk selalu melakukan pekerjaan yang bermanfaat bagi diri sendiri dan untuk orang lain. Karena semua amal akan dilihat oleh Allah, Rasul, serta para mukminin, dan akan diperlihatkan oleh Allah di hari kiamat kelak, kemudian akan mendapatkan balasan sesuai dengan amal perbuatannya ketika dimuka bumi. Jika amal perbuatan yang baik akan mendapat pahala, dan jika perbuatannya jelek akan mendapat siksa. (Muhammad Amin Suma, 2015)

Dari hal tersebut maka bisa ditarik kesimpulan bahwa Ayat di atas menerangkan tentang arti pentingya penilaian dari Allah, penilaian dari Rasul-Nya, dan juga penilaian orang-orang mukmin terhadap prestasi (kerja) hambanya. Semua prestasi itu pada saatnya nanti di akhirat, akan ditunjukkan dan diperlihatkan secara terbuka apa adanya, baik yang tidak terlihat maupun yang tampak. Singkatnya, setiap yang dikerjakan seseorang, dipastikan akan diberitakan atau dilaporkan secara apa adanya.

4) Istinbat

Istinbat Q.S At-Taubah ayat 105 ini pada hakekatnya memerintahkan semua dan setiap manusia untuk berusaha, bekerja dan lainnya, dikarenakan pekerjaan adalah sesuatu yang sangat penting untuk dilaksanakan. Setiap perbuatan amal atau usaha yang dilakukan, pasti akan diketahui oleh Allah SWT, Rasulullah SAW dan orang-orang beriman mencakup keseluruhan. Semua amal atau usaha yang dilakukan dipastikan akan menuai hasilnya baik berupa imbalan atau pembalasan, dan yang berhak memberikan pembalasan atau imbalan, itu adalah Allah Swt, Zat yang Maha Mengetahui hal-hal yang tampak dan hal yang tidak tampak atau gaib. Semua dan setiap perbuatan seseorang, baik maupun buruk kelak di akhiratakan diperlihatkan atau ditampilkan apa adanya. (Muhammad Amin Suma, 2015) 
b. Surah Al-Jumu'ah ayat 9-11

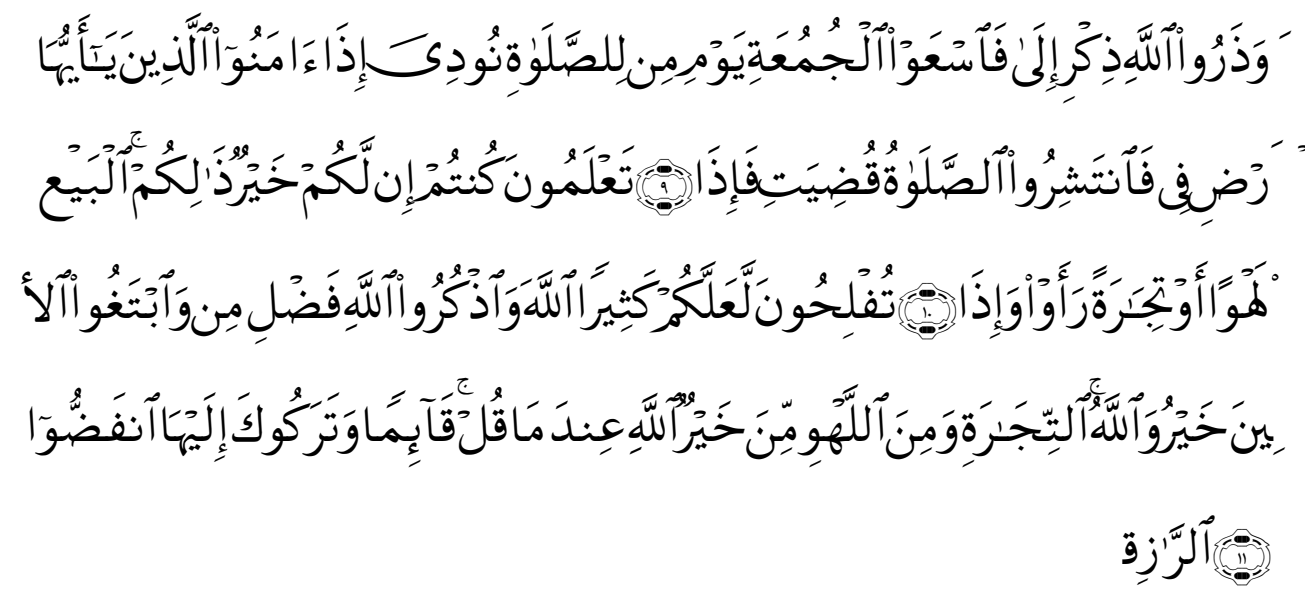

Artinya: "Hai orang-orang beriman, apabila diseru untuk menunaikan shalat Jum'at, Maka bersegeralah kamu kepada mengingat Allah dan tinggalkanlah jual beliyang demikian itu lebih baik bagimu jika kamu mengetahui.Apabila telah ditunaikan shalat, Maka bertebaranlah kamu di muka bumi; dan carilah karunia Allah dan ingatlah Allah banyak-banyak supaya kamu beruntung.Dan apabila mereka melihat perniagaan atau permainan, mereka bubar untuk menuju kepadanya dan mereka tinggalkan kamu sedang berdiri (berkhotbah). Katakanlah: "Apa yang di sisi Allah lebih baik daripada permainan dan perniagaan", dan Allah Sebaik-baik pemberi rezki." (Q.S. Al-Jumuah [62:09-11]).

1) Makna Mufradat

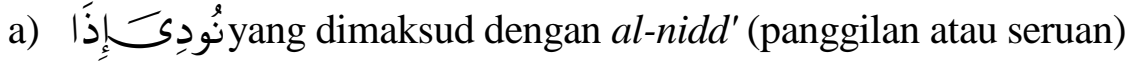

Dalam ayat ini adalah adzan, sebagaimana terdapat dalam Surah alMaidah (5): 58,| dalam hal ini adalah adzan shalat Jumat.

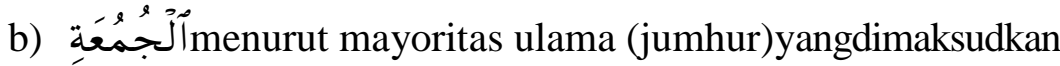
dengan Jumat di sini adalah hari Jumat, yaitu hari ke-6; dari tujuh hari dalam sepekan. Secara harfiah, Jumat artinya kumpul. Hari ini dinamakan hari Jumat (hari kumpul), karena di hari ini kaum i muslimin selalu berkumpul untuk melaksanakan shalat Jumat secara berjamaah. Berjamaah Jumat itu hukumnya wajib menurut kesepakatan ulama, meskipun tentang kepastian jumlah minimal 
jamaahnya berbeda-beda pendapat. Yang jelas, dibandingkan dengan hari-hari lain, hari Jumat memiliki keistimewaan tersendiri. Beberapa keistimewaan yang dimaksudkan misalnya adalah karena di hari ini, Jumat, ada kewajiban shalat Jumat yang hukumnya wajib bagi setiap muslim. Berbeda dengan shalat maktubah lain yang hukum berjamaahnya hanya setingkat sunnah muakkad (sunnah yang amat sangat dianjurkan) meskipun ada sedikit ulama yang mewajibkan, hukum wajib pelaksanaan shalat Jumat secara berjamaah justru telah menjadi kesepakatan ulama. Masih terkait dengan hari Jumat, juga satusatunya nama hari yang dijadikan nama surah dalam Alquran adalah hari Jumat, yaitu Surah al-Jumu'ah yang terdiri atas 11 ayat, 180 kata, dan 784 huruf.

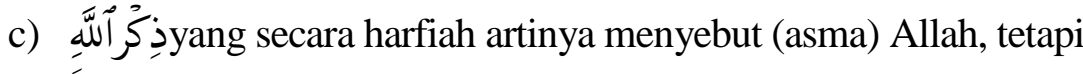
yang dimaksud dengan dzikrullah di sini adalah shalat, dalam konteks ini shalat Jumat. Kenapa shalat pada umumnya dan khususnya shalat Jumat itu disebut dengan dzikrullah ${ }^{7}$. Mengingat di dalam shalat itu dipastikan disebut asma Allah, tetapi belum tentu menyebut asma Allah itu selalu melalui shalat. Dengan kalimat lain, setiap shalat itu dipastikan tergolong ke dalam dzikir bahkan dzikir terbesar atau tertinggi (uia ladzikrulldhi akbar), sementara dzikir belum tentu berbentuk shalat apalagi setinggi atau sebesar shalat Jumat yang pelaksanaannya diharuskan secara berjamaah.

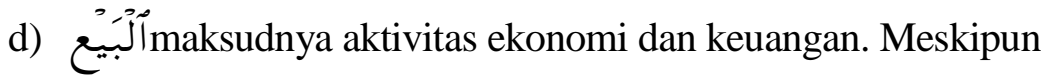
demikian, kata $a l^{\prime} b a i^{\prime}$ urnum diartikan dengan perdagangan, khususnya jual-beli. Namun demikian, sungguh menarik apa yang dikemukakan Syaikh Mahmud Syaltut, ketika menyatakan bahwa yang dimaksud dengan al-bai' dalam Alquran, sesungguhnya adalah setiap aktivitas (kerja atau usaha) yang bermotifkan 
ekonomi. Sehingga $a l^{\prime} b a i^{\prime}$ (jual-beli) itu tidak hanya tertuju kepada orang-orang yang berjualan di pasar, para petani di ladang, atau kebun, dan para buruh di pabrik. Akan tetapi, juga termasuk di dalamnya aktivitas jual'beli adalah para guru atau dosen di sekolah atau kampus, dokter dan perawat di rumah sakit, para pengacara, polisi, jaksa, dan hakim di pengadilan, tentara di medan tempur, konsultan di berbagai kantor dan tempat, dan lain-lain yang sangat luas jangkauannya.

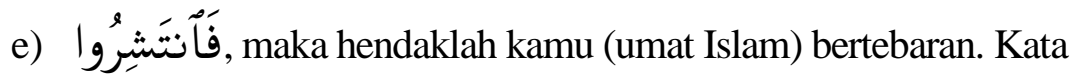
artinya terbentang, tersiar, tersebar, atau terpencar. Adapun yang dimaksud dengannya adalah bertebaran di muka bumi usai melaksanakan shalat Jumat.

f) فَضَل فألَّهِ terdapat perbedaan pendapat di kalangan ahli tafsir tentang; maksud dari kalimat ini. Salah satunya adalah rezeki dari jual-beli atau perdagangan sebagaimana dikatakan Muqatil dan alDhahhak. Ini sesuaipula dengan penggalan ayat yang menyatakan hadz\& min fadhli (Ini adalah rezeki dari Rabb-ku). (Muhammad Amin Suma, 2015)

2) Asbabun Nuzul

Menurut riwayat yang diterangkan oleh Jabir dalam tafsir s)afwatut-Tafsi>r, bahwa:

“ Saat Rasulllulah SAW melaskanakan khutbah Jum'at dengan keadaan berdiri, maka tiba-tiba datang kafilah dari Madinah. Maka para saahabat Nabi segera menuju kafilah itu sehingga tinggal dua belas orang, Abu Bakar dan Umar. Maka Allah menurunkan ayat, "Dan apabila mereka melihat perniagaan atau permainan, mereka bubar untuk menuju kepadanya dan mereka tinggalkan kamu sedang berdiri (berkhutbah)." (Mu'ammal Hamidy \& etc, 1987)

Pada saat Rasulullah Saw berdiri di atas mimbar dalam rangka memberikan khutbah Jumat. Waktu di tengah-tengah khutbah Jum'at, ada kafilah perdagangan yang tiba dari Syria (Syam), para pedaganng itu membawa makanan sehingga 
penduduka madinah pun tergoda untuk melihatnya, apalagi barang makanan pada waktu itu sedang dalam keadaan mahal. Adat istiadat mereka, begitu kafilah tiba, mereka berteriak-teriak atau sambil memukul-mukul lonceng dan lainnya yang menunjukkan kebahagiaan mereka. Saat kafilah tersebut semakin mendekat, banyak para kaum muslim yang sedang mendengarkan khutbah Jumat Rasullulah SAW pun keluar. Nyaris tidak ada jamaah yang tersisa, kecuali hanya sekitar 12 orang. Kata Jabir, sayalah salah satunya di antara yang 12 orang itu. (Mohammad Isa bin Surah At Tirmidzi, 1992)

Hal tersebut juga diperkuat oleh pendapat Abu Hayan meriwayatkan dalam tafsir al-Bahrul Muhith, bahwa sebabnya sampai mereka bubar yaitu karena penduduk Madinah pada saat itu ditimpa musim paceklik, dan harga barang-barang kebutuhan sangat tinggi. Maka ketika itu kafilah datang dengan membawa barang dagangan, sedang menurut adat kebiasaan mereka, bahwa kafilah yang masuk kota diharuskan memukul kendang dan bunyibunyian lainnya. Begitulah ketika kafilah itu masuk kota dengan bunyi-bunyiannya maka merek bubar untuk menontonnya, sedangkan Rasulullah SAW pada saat itu tengah berdiri diatas mimbar, yang dihadapan tinggal ada dua belas orang. Berkenaan dengan maksud larangan jual beli pada saat waktu pelaksaan shalat Jum'at yang dijelaskan dalam Q.S Al-Jum'ah [62]: 9 hendaknya kaum muslimin lebih mementingkan kehidupan akhirat dari pada kehidupan dunia (sementara). Tidak lama kemudian, turunlah ayat di atas. (Muhammad Amin Suma, 2015) 
3) Tafsir Ayat

Menurut pendapat Imam Al-Qurthubi dalam tafsir AlQurthubi Q.S Al-Jumu'ah [62]: 9-11, bahwa:

waktu yang diharamkan untuk bertransaksi, yaitu Pertama, menurut Adh-Dhahak, Hasan dan Atha, setelah matahari tergelincir hingga salat Jum'at berakhir. Kedua, menurut Syafi'I mulai dikumandangkannya azan saat imam akan berkhutbah, hingga salat Jum'at berakhir. (Taufik Damas \& Etc, 2013)

Firman Allah yang artinya "dan tinggalkanlah jual beli". Allah SWT melarang jual beli ketika shalat Jum'at. Allah mengharamkan hal itu pada waktu Jum'at atas siapa saja yang di khit fabi dengan kewajiban shalat Jum'at. Penjual ini tidak luput dari pembelian, oleh karena itulah Allah hanya menyebutkan salah satunya saja seperti firman Allah SWT dalam Q.S An-Nahl [16]: 8. (M. Quraish Shihab, 2002)

Allah mengkhususkan larangan pada jual beli, sebab jual beli merupakan aktivitas yang sering disibukkan orang-orang pasar. Dalam hal ini perlu dipahami bahwa orang yang tidak diwajibkan untuk menghadiri shalat Jum'at itu tidak dilarang untuk melakukan jual beli.

Adapun waktu diharamkannya melakukan jual beli dalam hal ini ada dua pendapat:

a) Adh-Dhahak, Al-Hasan dan Atha mengemukakan: Waktu diharamkannya melakukan jual beli adalah setelah matahari tergelincir sampai selesai shalat Jum'at.

b) Asy-Syafi'I mengemukakan: waktu diharamkannya transaksi jual beli di mulai dari adzan khutbah sampai waktu shalat.Mazhab Maliki mengungkapkan bahwa, seseorang yang diwajibkan untuk meninggalkan jual beli jika diseru untuk menunaikan shalat Jum'at. Menurutnya, transaksi jual yang berlangsung pada waktu itu harus dibatalkan. (M. Quraish Shihab, 2002) 
Dari paparan di atas dapat disimpulkan oleh penulis bahwa pendapat Imam Al-Qurthubi mengenai larangan transaksi jual beli pada saat khutbah Jum'at menyatakan bahwa jual beli yang dilakukan pada saat itu rusak dan batal karena waktu yang digunakan untuk melakukan aktivitas ekonomi bertepatan dengan pelaksanaan shalat Jum'at dan dapat menyibukkan diri seseorang sehingga mengalihkan kewajibannya kepada perintah Allah, pelarangan ini juga berlaku bagi orang-orang mukallaf, karena pelarangan ini tidak sesuai dengan Q.S Al-Jumu'ah ayat [62]: 9.sebagai mana yang diungkapkan oleh Ibnu Qudamah dalam tafsir Al Mughni yaitu orang yang tidak berkewajiban melaksanakan shalat Jum'at seperti musafir, anak kecil,wanita dan orang sakit, maka mereka melaksanakan shalat dzuhur. (Ibnu Qudamah, 2017) Selanjutnya menurut pandangan M. Quraish Shihab ayat di atas menyatakan:

Hai orang-orang beriman, apabila dpanggil yakni adzan berkumandang oleh siapa pun untuk shalat Jum'at pada waktu zuhur di hari Jum'at, maka berlekaslah dan bulatkan tekad dan langkah, jangan malas-malasan apalagi mengabaikannya, untuk menuju mengingat Allah SWT dengan menghadiri shalat Jum'at dam khutbah Jum'at, dan tinggalkanlah segala bentuk jual beli, yakni segala macam interaksi dalam bentuk dan kepentingan apapun bahkan semua yang dapat mengurangi perhatian terhadap kesakralan shalat Jum'at. Demikian itulah kebaikannya pastilah kamu mengabaikan perintah ini'. (M. Quraish Shihab, 2002).

Ayat-ayat ini memerintahkan kepada orang-orang beriman disarankan untuk segera menunaikan shalat Jumat ketika adzan dikumandangkan. Kata al-bai di dalam ayat ini digunakan dengan maksud meliputi semua hal kegiatan muamalah yang tidak hanya berniaga dalam arti sempit. Kegiatan muamalah apa pun yang dilakukan pada waktu itu, pada dasarnya harus segera ditinggalkan 
begitu kumandang adzan Jumat dikumandangkan, kecuali ada halangan atau uzur yang membolehkan untuk tidak menunaikan shalat Jumat dan dapat diganti dengan shalat Zhuhur. Salah satunya adalah orang sakit dan musafir (melakukan perjalanan yang melelahkan dan sempit waktunya), hamba sahaya, wanita, anak-anak.

Di zaman modern sekarang ini, banyak pula aktivitas tertentu yang apabila ditinggalkan akan menimbulkan mudarat (bahaya) dan mengancam banyak orang atau bahkan kepentingan umum. Misalnya, para petugas keamanan di pos-pos tertentu yang memerlukan pengamanan sepanjang waktu; atau pnbrik-pabrik tertentu yang operasinya berjangka lama, dan apabila dihentikan barang sesaat saja, diduga kuat akan mengalami kerugian besar. Terhadap parapetugas seperti ini, dibolehkan tidak melaksanakan shalat Jumat dan tetapi tetap berkewajiban untuk melaksanakan shalat Zhuhur.

Selanjutnya terkait dengan hal meninggalkan kegiatan bisnis dan aktivitas duniawi lainnya untuk sementara waktu demi menunaikan shalat Jumat. Karena hal demikina lebih baik bagi kalian jika kamu benar-benar orang yang mengetahui, menghayati, dan menjiwai pensyariatan dari shalat Jumat. Kata lebih baik di sini, hampir dapat dismpulkan tidak sebatas dari sudut pandang ibahda semata saja, Akan tetapi juga dipandang dari sisi lainnya, termasuk dari segi keberkahan perekonomian dan keuangan yang tidak akan pernah merugi.

Jikalau sudah menghadiri seruan adzan Jumat dan selesai menunaikan shalat jumat, maka dipersilahkan kembali untuk bertebaran kembali di muka bumi, untuk berdagang atau melakukan aktivitas lain yang membawa mashlahat bagi kehidupanmu, dan silakan juga mencari pemberian Allah dan nikmat-Nya, mengingat Pemberi rezeki yang sesungguhnya adalah Allah, Dzat Pemberi nikmat (al-mun'im) dan Yang Maha Pemberi (al'mutafadhdhil), yang tidak pemah menyia-nyiakan prestasi dan profesi seseorang, dan Dzat yang 
tidak pernah mengecewakan (menghilangkan harapan) orang yang meminta kepada-Nya. (Muhammad Amin Suma, 2015).

Berdasarkan paparan di atas, maka menurut penulis pada waktu khutbah jum'at dilarang melakukan segala transaksi berlaku kepada semua kaum mukallaf, karena semua kaum muslimin diperintahkan untuk segera melakukan shalat Jum'at bagi yang diwajibkan dan kepada golongan yang tidak diwajibkan untuk melakukan shalat Jum'at maka diperintahkan untuk melaksanakan shalat dzuhur. Bagaimanapun sesibuk-sibuknya orang-orang beriman pada hari Jumat dikarenakan sedanga melaksanakan aktivitas muamalah, ketika adanya seruan adzan Jumat dikumandangkan, maka orang-orang beriman harus bersegera meninggalkan aktivitas muamalah tersebut untuk melaksanakan shalat Jumat secara di Mesjid. Setelah selesai melaksanakan shalat Jumat, kemudian dipersilahkan untuk kembali melaksanakan aktivitas muamalah seperti dilakukan sebelum masuk waktu shalat Jumat. (Muhammad Amin Suma, 2015)

4) Istinbat

Menurut pandangan Quraish Shihab bahwa terdapat pelajaran yang dapat diambil dari Q.S Al Jumuah ayat 9-11, yaitu:

a) Menjadikannya kewajiban setiap pria untuk meninggalkan segala aktivitas, sejak dikumandangkannya adzan dan khatib naik ke mimbar

b) Shalat Jum'at dan khutbah Jum'at adalah seruan utnuk mengingat Allah SWT, karena itulah sehingga ayat di atas menggunakan kata dzikrullah.

c) Bergegas menuju masjid dalam hal untuk melaksanakan shalat Jum'at bukan berarti berlari atau berjalan cepat, apalagi ada perintah Nabi SAW yang menyatakan: "Apabila shalat telah segera akan dilaksanakan (iqamat), maka jangan menuju ke sana dengan berjalan cepat (sa'i), tetapi hadirilah dengan sakinah (ketenangan dan penuh wibawa. Bagian shalat yang kamu dapati, maka lakukanlah dan yang tertinggal sempurnakanlah" (HR. Bukhari Muslim).

d) Shalat Jum'at dilaksanakan sebagai pengganti shalat zuhur, karena itu tidak lah wajib atau dianjurkan yang telah shalat Jum'at untuk 
melakukan shalat zuhur. Dua kali khutbah Jumat dinilai menggantikan dua rakaat zuhur.

e) Ayat di atas menunjukkan kepada orang-orang beriman, yang dapat mencakup pria dan wanita, baik yang bermukmin di Negara tempat tinggalnya, maupaun yang musafir. Namun Nabi SAW menjelaskan 'Shalat Jum'at adalah keharusan yang wajib bagi setiap Muslim untuk dilaksanakan dengan berjamaah, kecuali terhadap empat golongan (kelompok), yaitu hamba sahaya, wanita, anak-anak, dan orang sakit.

f) Walaupun perempuan tidak diwajibkan untuk melaksanakan shalat Jum'at, tetapi bila mereka melakukannya bersama jamaah lain, maka shalatnya sah dan mereka tidak perlu lagi shalat zuhur. (M. Quraish Shihab, 2002)

Lebih lanjut dari ayat di atas menurut Prof. Amin Suma, istinbat ayat ini dapatlah disimpulkan dalam beberapa poin.

a) Pada dasamya, Allah tidak melarang orang-orang mukmin untuk beraktivitas keduniawian (muamalah) di hari Jumat, asalkan tetap melakukan shalat Jumat yang hukumnya wajib itu. Kecuali karena atas dasar uzur syar'i.

b) Batas toleransi berbisnis atau kegiatan lainnya di Hari Jumat, sampai adzan Jumat dikumandangkan. Ketika adzan Jumat dikumandangkan mu'adzin, semua aktivitas duniawi yang disimbolkan dengan usaha ekonomi, harus segera ditinggalkan, tidak terkecuali aktivitas berbisnis yang menggiurkan keuntungan material.

c) Usai melaksanakan shalat jum'at, orang-orang beriman dibolehkan kembali bertebaran di muka bumi untuk melakukan berbagai aktivitas keduniaan. Ini mengisyaratkan prinsip keseimbangan antara ibadah di satu pihak dengan muamalah pihak lain. (Muhammad Amin Suma, 2015) 


\section{Kedudukan Kerja dalam Islam}

Dari ayat tersebut Alquran Surah At-Taubah ayat 105 dan Surah AlJumuah ayat 9-11 tentang urgensitas bekerja dalam Islam dan Allah sangat menganjurkan umatnya untuk bekerja dikaernakan kedudukan kerja dalam Islam itu menduduki posisi yang sangat penting karena kerja sebagai penopang untuk pemenuhan kebutuhan manusia.Islam menempatkan kedudukan kerja pada tempat yang sangat mulia dan luhur yaitu dikelompokkan pada fisabilillah. Hal ini tercermin dari sabda Rasullulah SAW yang diriwayatkan oleh Thabrani dari bukunya Toto Tasmara yang artinya: (Toto Tasmara, 2002)

"Diriwayatkan dari Ka'ab bin Umrah: Ada seseorang yang berjalan melalui tempat Rasullulah SAW bahwa orang itu sedang bekerja dengan sangat giat dan tangkas. Para sahabat lalu berkata: "Ya Rasullulah, andaikata bekerja semacam orang itu dapat digolongkan fisabillilah, alangkah baiknya". Maka Rasullulah bersabda: "Kalau ia bekerja untuk membela kedua orang tuanya yang sudah lanjut usia, ia itu fisabillilah. Kalau ia bekerja untuk kepentingan dirinya sendiri agar tidak meminta-minta, ia adalah $f i$ sabillilah. (HR Thabrani).

Dari hadits tersebut dapat diambil itibar bahwa kedudukan kerja dalam Islam ditempatkan dalam posisi yang sangat mulia dan luhur. Hal ini sebagaimana hadis nabi tersebut menejelaskan pentingnya bekerja dengan bersungguh-sungguh maka hal ini disamakan dengan jihad fisabillilah. Berjuang di jalan Allah dikarenakan dengan bekerja maka akan meningkatkan taraf hidup tidak menjadi peminta-minta. Dengan bekerja pula kita bisa menghidupkan syiar agama dengan menolong para fakir miskin dengan kelebihan harta dengan jalan zakat, sedekah, infak, dan yang lainnya.

Lebih Lanjut menurut Nurcholish Madjid, tentang urgensi bekerja dalam Islam adalah kepercayaan umat Muslim, bahwa kerja mempunyai relasi dengan tujuan dari kehidupannya, yaitu untuk memperoleh kerdidhaan dari Allah Swt. Hal ini sangat penting untuk ditegaskan bahwa pada dasarnya, Islam adalah agama amal atau kerja. Inti dalam ajaran Islam adalah bahwa kita sebagai hambamya selau berusaha dalam memperoleh keridhaan Allah SWT melalui kerja atau amal saleh, dan dengan memurnikan sikap penyembahan hanya kepada-Nya.(Nurcholish 
Majid, 1995) Sehingga kedudukan kerja dalam Islam ditempatkan dalam posisi yang sangat mulia dan luhur sebagai salah satu wujud ibadah kita kepada Allah SWT.

Untuk mewujudkan nilai-nilai ibadah dalam bekerja yang dilakukan oleh setiap insan, diperlukan adab dan etika yang membingkainya, sehingga nilai-nilai luhur tersebut tidak hilang sirna siasia. (Maulana Rizkan, t.t.) Diantara adab dan etika bekerja dalam Islam adalah:

a. Hendaknya bekerja Ikhlas karena Allah SWT, Hal ini merupakan landasan yang terpenting untuk seseorang yang melakukan perkerjaan. Niat utama harus karena Allah SWT ketika melaksanakan suatu pekerjaan. Memahami bahwa bekerja adalah kewajiban dari Allah SWT yang harus dilakukan oleh setiap hamba. Memberikan nafkah kepada diri sendiri maupun keluarga adalah kewajiban yang diperintahkan oleh Allah SWT. Bahwa hanya dengan bekerja dapat menunaikan kewajiban-kewajiban Islam yang lainnya dalam menolong orang lain, seperti sumbangan, zakat, infak dan shodaqah. Sehingga akan selalu memulai aktivitas pekerjaannya dengan dzikir kepada Allah SWT.

b. Bekerja dilaksanakan denga penuh Itqon atau profesional, tekun dan sungguh-sungguh. Ini merupakan penerapan ikhlas dalam bekerja adalah itqon atau sering juga disebut profesional dalam bidangnya atau pekerjaannya. Dalam bekerja agar selalu hadir tepat pada waktunya, menyelesaikan apa yang sudah menjadi kewajibannya samapi selesai, tidak mengabaikan pekerjaan, , tidak menunda-nunda pekerjaan adalah bagian yang tidak terpisahkan dari pekerjaan itu sendiri yang merupakan salah satu ibadah kepada Allah SWT. Menurut sebuah riwayat hadits, riwayat Aisyah ra, bahwa Rasulullah SAW bersabda, "Sesungguhnya Allah SWT mencintai seorang hamba yang apabila ia bekerja, dia itqon menyempurnakan dalam pekerjaannya." (HR. Thabrani). 
c. Bekerja dengan selalu mengamalkan sifat nabi berupa Jujur dan amanah. Karena pada hakekatnya pekerjaan yang dilaksanakan adalah suatu amanah, baik secara duniawi dari pimpinannya atau pemilik usaha, ataupun secara duniawi dari Allah SWT yang akan dimintai pertanggung jawaban atas pekerjaan yang dilakukan. Penerapan jujur dan amanah dalam bekerja adalah dengan tidak melakukan perbuatan curang, mengambil sesuatu yang bukan haknya, obyektif dalam menilai sesuatu hal, dan lainnya. Bahkan Rasulullah SAW sampai memberikan janji bagi orang yang jujur dan amanah akan masuk ke dalam surga bersama para shiddiqin dan syuhada'. Hal ini ada dalam hadit yang diriwayatkan At Turmudji: Dari Abu Said Al-Khudri RA, beliau berkata bahwa Rasulullah SAW bersabda, "Pebisnis yang jujur lagi dipercaya (anamah) akan bersama para nabi, shiddiqin dan syuhada'.

d. Bekerja sebagai seorang muslim haruslah menjaga etika. Adab dan etika dalam bekerja sebagai seroang muslim haruslah dijaga, seperti: etika dalam bermuamalah, etika dalam bergaul, etika dalam bersosial, dan sebagainya. Bahkan akhlak atau etika ini merupakan ciri kesempurnaan iman seorang mukmin. Bekerja dituntut untuk bertutur kata yang sopan, bijak dalam bersikap, makan dan minum sesuai dengan tuntunan Islam, berhadapan dengan pelangggan dengan cara yang baik, apabila ada rapat bersikap yang terpuji dan sebagainya yang menunjukkan diri sebagai seorang yang beriman. Bahkan dalam hadits Rasulullah SAW menggambarkan bahwa terdapat dua sifat yang tidak mungkin terkumpul dalam diri seorang mukmin, yaitu bakhil dan akhlak yang buruk. (HR. Turmudzi).

e. Bekerja dengan tidak melanggar prinsip-prinsip syariah. Aspek ini sangatlah penting daslam Islam adalah tidak boleh melanggar prinsipprinsip syariah dalam pekerjaan. Tidak melanggar prinsip syariah ini dapat dikelompokkan menjadi beberapa hal, yakni: 
1) Dari sisi substansi atau zat dari pekerjaannya, seperti tidak diperbolehkannya memproduksi barang yang haram, menyebarluaskan kefasadan seperti penebar kebencian, pornografi dan permusuhan, riba, risywah atau suap dan sebagainya.

2) Dari sisi penunjang yang tidak terkait langsung dengan pekerjaan, seperti tidak menutup aurat, ikhtilat adanya batasan antara laki-laki dengan perempuan, membuat fitnah dalam persaingan dan sebagainya.

Pelanggaran-pelanggaran terhadap prinsip syariah, dapat mengakibatkan dosa dan juga menjadi sebab harta tidak berkah, juga dapat menghilangkan pahala amal saleh kita dalam bekerja. Allah SWT berfirman:

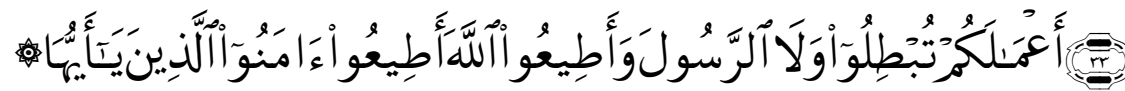

"Hai orang-orang yang beriman, taatlah kepada Allah dan taatlah kepada Rasul-Nya dan janganlah kalian membatalkan amal perbuatan atau pekerjaan kalian.."( Q.S. Muhammad [47:33] ).

f. Pekerjaan yang terhindar dari unsur syubhat. Syubhat atau sesuatu yang samar-samar atau meragukan antara unsur halal dan unsur haramnya terkadang menjadi masalah dalam pekerjaan. Contohnya dalam pekerjaan adanya pemberian dari pihak luar, yang terdapat indikasi adanya satu kepentingan tertentu. Selain itu juga bekerja sama dengan pihak-pihak yang secara umum diketahui kedzhaliman atau pelanggarannya terhadap aturan syariah. Syubhat dalam pekerjaan dapat berasal dari faktor eksternal maupin faktor internal. Karena hal itulah, seorang muslim dalam melaksanakan pekerjaannya hati-hati dengan hal tersebut. Menurut hadits Rasulullah SAW bersabda,

"Halal itu jelas dan haram itu jelas, dan diantara keduanya ada perkara-perkara yang syubhat. Maka barang siapa yang terjerumus dalam perkara yang syubhat, maka ia terjerumus pada yang diharamkan..." (HR. Muslim). 
g. Selalu menjaga ukhuwah Islamiyah antara sesama muslim. Bekerja atau berusaha janganlah sampai melahirkan perpecahan di antara sesama muslim. Rasulullah SAW sendiri mengemukakan tentang hal yang bersifat pencegahan agar tidak merusak rasa ukhuwah Islamiyah di kalangan kaum muslimin. Rasullulah SAW mengemukakan dalam sebuah hadits, "Dan janganlah kalian menjual barang yang sudah dijual kepada saudara kalian" (HR. Muslim). Karena jika terjadi pertentangan dari hadits ini, tentu akan merenggangkan juga ukhuwah Islamiyah. Terkadang masalah pekerjaan ataupun usaha yang menghasilkan uang, akan sangat sensitif bagi para pelaku diantara mereka; apabila sikap saling curiga, berprasangka buruk dan lainnya sudah ternodai oleh sifat tersebut sangat diperlukannya sikap Ukhuwah Islamiyyah. (Maulana Rizkan, t.t.)

Dari hal tersebut penulis mengambil itibar bahwa meskipun kedudukan kerja dalam Islam ditempatkan dalam posisi yang sangat mulia dan luhur sebagai salah satu wujud ibadah kita kepada Allah SWT untuk mewujudkan hal tersebut dalam nilai-nilai yang dapat diambil dalam dalam bekerja yang dilakukan oleh setiap manusia, yakni diperlukan adab dan etika yang membingkainya, sehingga nilai-nilai luhur akan selalu terjaga dan tidak hilang sia-sia.

\section{Kesimpulan}

Bekerja adalah untuk mencari nafkah atau mata pencahairan dalam memenuhi kebutuhannya untuk bertahan atau melangsungkan kehidupannya. Dalam Islam bekerja bisa sebagai penopang kehidupan dan juga sebaga sarana dalam beribadah kepada Allah SWT, sehingga sangatlah penting atau urgensi bekerja dalam Islam agar dilaksanakan dengan sebaik-baiknya demi mendapatkan keridhaan Allah SWT.

Urgensi bekerja dalam Alquran Surah At-Taubah ayat 105 mengenai perintah bekerja keras yang akan menuaikan hasil yang baik serta juga mengisyaratkan bahwa tentang arti pentingmya penilaian pekerjaan dari Allah, 
penilaian dari Rasululah, dan penilaian orang-orang mukmin terhadap prestasi kerja seseorang dalam bekerja. Selanjutnya dalam Alquran Surah Al-Jumuah ayat 9-11 yaitu tentang perintah bekerja apabila semua kewajiban terhadap Allah sudah ditunaikan maka dipersilahkan untuk kembali melakukan aktivitas ekonomi atau bekerja, mengenai perintah bekerja dan beribadah, ketika bekerja jangan melupakan ibadah karena tidak hanya dunia yang diutamakan, akherat juga harus diutamakan. Harus adanya keseimbangan antara pekerjaan dan juga ibadah.

Kedudukan kerja dalam Islam ditempatkan dalam posisi yang sangat urgensi, mulia dan luhur sebagai salah satu wujud ibadah kita kepada Allah SWT untuk mewujudkan hal tersebut dalam nilai-nilai yang dapat diambil dalam dalam bekerja yang dilakukan oleh setiap manusia, yakni diperlukan adab dan etika yang membingkainya, sehingga nilai-nilai luhur akan selalu terjaga dan tidak hilang sia-sia. 


\section{DAFTAR PUSTAKA}

Ibnu Qudamah. (2017). Al Mughni. Jakarta: Pustaka Azzam.

Jalaluddin As-Suyuthi. (2009). Lubabun Nuqul fii Asbaabin Nuzul. Jakarta: Gema Insani.

Kutub al-Tis'ah. (t.t.). Imam Bukhari (Kitab : Jual beli Bab : Usaha dan kerja seseorang dengan tangannya No. Hadist : 1930).

M. Quraish Shihab. (2002). Tafsir Al-Mishbah Jilid 2 "Pesan, Kesan dan Keserasian Alquran. Jakarta: Lentera Hati.

Maulana Rizkan. (t.t.). Etika dan Akhlak Bekerja dalam Islam [blog]. Diambil 29 Oktober 2018, dari http://rikzamaulan.blogspot. co.id/2009/01/etika-danakhlak-bekerja-dalam-islam.html

Mohammad Isa bin Surah At Tirmidzi. (1992). Terjemah Sunan At Tirmidzi Jus v. Semarang: CV. Asy Syifa.

Mu'ammal Hamidy, \& etc. (1987). Tafsir Ayat Ahkam as-Shabuni. Surabaya: PT. Bina Ilmu.

Muhammad Amin Suma. (2015). Tafsir Ayat Ekonomi (Teks, Terjemah, dan Tafsir). Jakarta: Amzah.

Nurcholish Majid. (1995). Islam Agama Kemanusiaan: Membangun Tradisi dan Visi Baru Islam Indonesia. Jakarta: Paramadina.

Taufik Damas, \& Etc. (2013). Tafsir Jalalain Perkata. Jakarta Timur: PT. Suara Agung.

Tim Penyusun. (2008). Kamus Besar Bahasa Indonesia. Jakarta: Pusat Bahasa. Toto Tasmara. (2002). Membudayakan Etos Kerja yang Islami. Jakarta: Gema InsaniPress. 